Journal of Science Education Research

\author{
Journal homepage: www.journal.uny.ac.id/jser
}

\title{
JSER
}

\section{Developing HOT-LAB-Based Physics Practicum E-Module to improve Practicing critical thinking skills}

\author{
Riki Purnama Putra ${ }^{1 *}$, Rena Denya Agustina $^{2}$, Pina Pitriana ${ }^{3}$, Shidiq Andhika ${ }^{4}$, Moh Diki Setia \\ Dermawan $^{5}$, Elsya Nurfadillah ${ }^{6}$ \\ 1,2,3,4,5,6 Study Program of Physics Education, Faculty of Tarbiyah and Teaching, UIN Sunan Gunung Djati \\ Corresponding Author. Email: purnamariki20@gmail.com
}

\section{Keywords: \\ 21st Centuries \\ Skills, Critical \\ Thinking Skills, E- \\ Module, HOT-LAB}

\begin{abstract}
Practicum activity is a scientific process to find out a phenomenon or validate a concept. HOT-LAB in laboratory activities is useful in improving $4 \mathrm{C}$ skills, including Critical Thinking Skills. The number of Modules or E-Modules that use a cookbook of guided laboratory inquiries was less to increase the 4C Skills in supporting the 21st Century skills. This study aimed to design, create and find out the effect of using HOT-LAB-based EModules to improve the students' Critical Thinking Skills. The research method was the ADDIE RnD. Invalidation stage, E-Module that was validated by material and media validators, stated effective, so it was feasible to continue to data collection of students. Data of Critical Thinking Skills used 30 students as subjects whose raw data was analyzed using statistical tests. E-Module obtained a validity score of $83.33 \%$ on the material validation and $84.6 \%$ on the media validation. Moreover, the statistical test showed that there is a significant change in implementing E-Module, which means that the HOT-LAB-based EModule improved the students' Critical Thinking Skills.
\end{abstract}

C2021 JSER. Universitas Negeri Yogyakarta

\section{INTRODUCTION}

Laboratory activities may be used as an alternative activity to explore and maximize the potential of students (Eka Astika et al, 2020). A physics learning system that uses practicum activities, in general, is the practicum with a real laboratory. Real laboratories in investigations or experiments carried out with the assisted by threedimensional media (Hikmawati et al., 2019). Physics practicum learning systems are usually carried out in a face-to-face meeting in a laboratory room.

Through conventional learning, the attitude of independence learning to practice is less motivated. Then, E-module is developed to overcome the conditions. Physics practicum using E-Module used electronic media, especially network system of internet computer (Brooks \& Brooks, 1999). Adisendjaja (Laelasari \& Adisendjaja, 2018), research on learning activities and responses to learning through simple laboratory activities, found out that students are motivated to find and actively discuss in a group.

Laboratory activities also require students to develop critical thinking. Government Regulation of the Republic of Indonesia Number 19 of 2005 on National Education Standards states that every university must teach students with skills, such as Critical Thinking Skills, Creative Thinking, Cooperative thinking, literacy of ICT, and other important skills in the 21st century (Makiyah et al., 2019). Curriculum 2013 (K13) also requires communication technology in the learning process (Syafitri et al., 2019).

Lastriningsih (2017) states that critical thinking skills can improve student achievement, including the field of knowledge that is shown by the percentage of completeness criteria by $80 \%$, attitude by $90 \%$, and skill by $80 \%$. Besides creative thinking, problem-solving, and reflective thinking, John Dewey in Fisher (2009) stated that 'critical thinking is 'reflective thinking' and defines it as an active, continuous and careful consideration of 
knowledge toward a belief or knowledge. And, it accepts many supporting reasons and further conclusions (De, 1933).

Nurhadi (2018) argues that a good laboratory will support good laboratory activities as well. A good laboratory is a laboratory with good management and covering various processes, namely (1) planning is a process to think and determine the facilities and infrastructure of the laboratory to achieve the objectives of the laboratory activities; (2) Procurement is an effort to implement the planning; (3) Inventory is the activity of recording the facilities; (4) good storage management perform to maintain the facilities and equipment in a good condition; (5) The laboratory management, starting from the layout, lighting, distance from other buildings, and so on; (6) use the facilities and infrastructure effective and efficient; (7) maintenance; (8) Eliminating unnecessary facilities and infrastructure. The research and expert opinion on the importance of critical thinking arise ideas for innovation in practical activities through the development of practical models (Hoftein \& Lunetta, 2003).

Models commonly used in laboratory activities include; (1) cookbook laboratory whose activities are focused on procedures without involving students to think about the things to do that aim to understand the concepts studied in the laboratory(Luckie et al., 2013); (2) Inquiry Guided Laboratory emphasizes students to construct knowledge through active scientific investigation, namely by conducting pre-lab activities to activate knowledge within students and help students to understand the concept (SETIABUDI NINGTYAS \& ROSDIANA, 2019); (3) HOTLAB (High Order Thinking Laboratory) emphasize students perform exploratory and independent laboratory activities following the advance of 4C Skills in 21st Century to teach students with future skills and also synergy among teacher and students (Malik, Adam; Setiawan, Agus; Suhandi, Andi; Permanasari, 2018). Compared to other laboratory activity models, the HOT-LAB model has advantages, including improving students' critical and creative thinking skills (Putra et al., 2021).

In the process, practical instructions train and develop higher-order thinking skills, called as Higher Order Thinking Laboratory (HOT Lab). HOT Lab may manifest into a real laboratory activity, Higher Order Thinking Real Lab (HOTRL) or virtual laboratory, and Higher Order Thinking Virtual Lab (HOTVL). Using this model, practical activities emphasize problem-solving using higherorder thinking skills which consist of processes, such as; (1) understand the challenge, (2) create ideas, (3) preparation for laboratory, and (4) evaluate the results. Makiyah et al (2019), this laboratory design consist of 11 phases of activities, including real-world problems, determining and evaluating ideas, experimental questions, materials and tools, predictions, conclusions, and presentations (Makiyah et al., 2019).

Through physics practicum learning using an e-module, the practitioner has the widest opportunity to participate in determining the objectives, sources, and evaluation of learning. Thus, the practitioner has responsibility in managing and disciplining to learning, not depend on conventional learning conditions (Wena, 1970). The rapid development of technology, makes everyone, including students, familiar with Android. This rapid development, especially in the pandemic conditions that occurred all around the world, makes E-Modules need to be developed for learning. EModule is a module with an electronic format and runs on a computer (Laili, 2019). E-Module is a learning resource containing materials, methods, limitations, and ways of evaluating that are designed systematically and attractively to achieve competence electronically (Laili, 2019; Putra \& Anjani, 2020). E-modules are independent teaching materials containing audio, video, and animation that are presented in electronic form and combined with a link to create more interactive learning (Ministry of Education and Culture, 2017). Compared to printed modules, E-Module has advantages, such as interactive, which allows displaying or loading images, audio, video, and animation. The addition of these contents allows immediate automatic feedback (Suarsana \& Mahayukti, 2013).

Not only demand the involvement of ICT in the learning process but the curriculum 2013 (K13) also demands critical thinking skills. Higher Order Thinking Skills (HOTS) is the ability to integrate the skills to connect, manipulate, and transform knowledge and experience into thinking processes in decide the choices and answer the problems (Rofiah et al., 2013). The developed E-Module is a HOTLAB (Hight Order Thinking Laboratory) EModule in a virtual laboratory, complete with practical activities that emphasize problem-solving using critical thinking skills and consists of processes, namely (1) understanding challenges/ problems, (2) create ideas, (3) perform laboratory activities, (4) produce a result or solve the problem (Makiyah et al., 2019). HOT LAB activities can train and develop 21st-century skills following the National Education Standards.

By the development of the HOT-LAB-based E-Module, the product is oriented to train critical thinking skills and creative problem solving through practical work, involving physics materials. The study aimed to develop E-Module for physics practicum in carrying out laboratory activities that 
are exploratory and easy to understand by practitioners during the laboratory activities.

\section{METHOD}

\section{Time, Place, And Number Of Subjects}

The subject was 30 students of Physics Education in the second semester in UIN Sunan Gunung Djati Bandung. The research was conducted in May 2021.

\section{Research Approaches and Methods}

The study uses the Research and Development (RnD) method with the ADDIE model, which is a development model consisting of five stages; (1) Analysis (2) Design (3) Development (4) Implementation (5) Evaluating. The framework of the ADDIE research is presented in Figure 1.

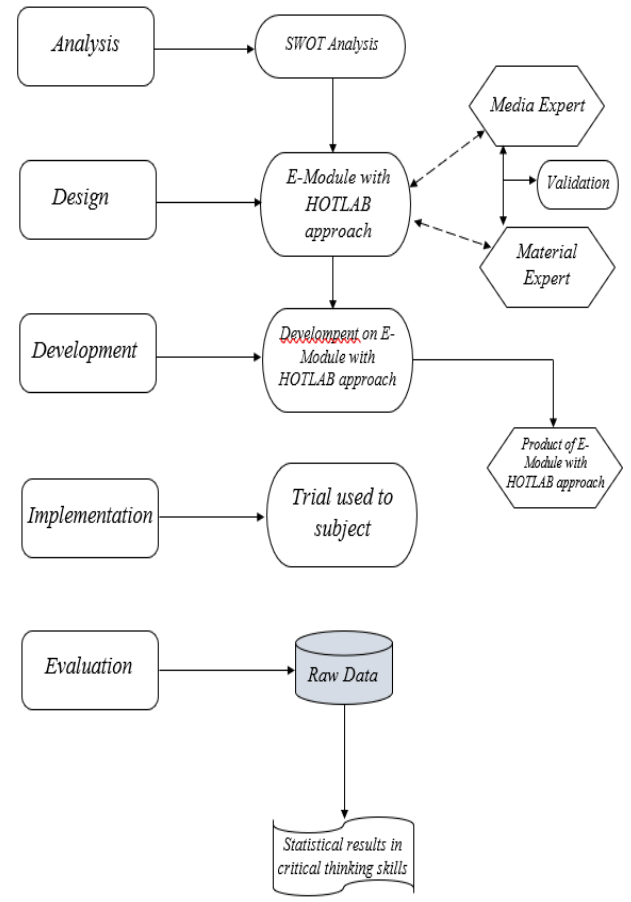

Figure 1. RnD Framework with ADDIE Model

The validation of HOT LAB-based E-Module was validated by competent validators; media and material experts. Furthermore, the validator provided general assessments and suggestions on the product of HOT LAB-based E-Module, whether the HOT LAB-based E-Module was valid or invalid.

The data analysis technique during the validation was descriptive analysis, which calculated the percentage score of the validation results.

$$
=\frac{f}{n} x 100 \%
$$

$P \quad=$ Percentage

$f \quad=$ Obtained Score

$n \quad=$ Maximum Score

The level of feasibility is identified by the scores. The criteria for validation was presented in Table 1.
Table 1. Validity Criteria on E-Module

\begin{tabular}{ccc}
\hline No & Percentage & Explanation \\
\hline 1 & $80 \%-100 \%$ & Valid \\
2 & $60 \%-79.99 \%$ & Fairly Valid \\
3 & $50 \%-59.99 \%$ & Poor Valid \\
4 & $0 \%-49.99 \%$ & Invalid \\
\hline
\end{tabular}

After the validation process, it continued to stage of sampling on the research subjects to reduce members of the population to members of a representative sample using the Slovin technique with the following equation:

$$
n=\frac{N}{N d^{2}+1}
$$

$N \quad=$ Population

$n \quad=$ Number of sampel

$d \quad=$ Precision, with $10 \%$ precision and confident level of 95\% (Aji, 2007)

After that, true experiment research with two classes was used to calculate the level of Critical Thinking Skills. The research design was presented in table 2.

Table 2. Pretest-Posttest Control Group Design

\begin{tabular}{ccccc}
\hline $\begin{array}{c}\text { Sam } \\
\text { ple }\end{array}$ & Class & $\begin{array}{c}\text { Pre } \\
\text { test }\end{array}$ & $\begin{array}{c}\text { Tr } \\
\text { eat } \\
\text { me } \\
\text { nt }\end{array}$ & Posttest \\
\hline Ran & Experiment & $\mathrm{X}_{1}$ & $\mathrm{P}_{1}$ & $\mathrm{X}_{2}$ \\
dom & Control & $\mathrm{Y}_{1}$ & & $\mathrm{Y}_{2}$ \\
\hline
\end{tabular}

Where: $\mathrm{X}_{1}=$ Pretest before treatment in the experimental class; $\mathrm{X}_{2}=$ Posttest after treatment in the experimental class; $Y_{1}=$ Pretest before treatment in the control class; $\mathrm{Y}_{2}=$ Posttest after treatment in the control class; $\mathrm{P}_{1}=$ Treatment in the experimental class

The pretest and posttest on critical thinking skills were the measured indicators in the study. The instrument was questions of practical and conceptual understanding with a total approximately of 10 questions.

\section{RESULT}

The research produced a product, a HOT LAB-based E-Module. The laboratory activity module was created and designed by researchers, with the aim as a tool for lecturers or teachers in performing laboratory activities that are exploratory and easy to understand during laboratory activities. And, it aimed to build a more structured and measurable research framework before practicum.

The research conduct all the stages of development research with the ADDIE model. The stages of development research include:

1. Analysis, the analysis phase of the product development consisted of analysis of the 
materials and media of the modules. The analysis produces materials that are used and needed in laboratory activities of Basic Physics 2 subject and a HOT LAB-based E-Module to be a guidebook for practicum laboratory activities of Basic Physics 2. The model is a HOT LAB that aims to make exploratory laboratory activities.

2. Design. at the design stage carried out the steps of; 1) designing the layout of HOTLAB-based EModule, 2) Select and input the materials into the module, 3) Validation of media and material experts.

3. Development. The results of the development stage were 1) Application of the HOT LAB on the E-Module of basic physics 2. Each material in this module consisted of Real-World Problems, Pre-Lab stages, Lab stages, and PostLab stages. And, 2) Validation scores media. The product was presented in Figure 2.
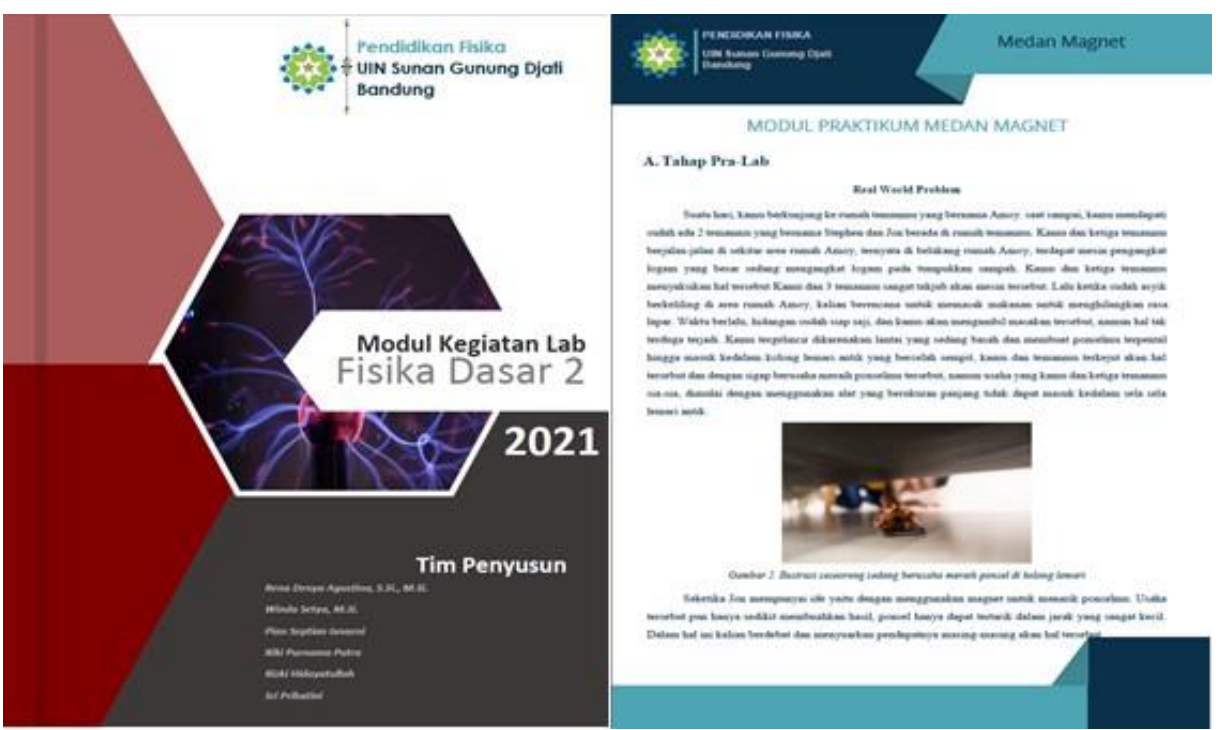

Figure 2. HOT LAB on the E-Module of basic physics 2

4. Implementation. It implemented the product to the subjects. They were the second-semester students of Physics Education at UIN Sunan Gunung Djati Bandung, dividing into two classes (Experimental and Control) to find out the results of the evaluation.

5. Evaluation. The final stage was to determine the level of critical thinking skills that were presented in statistical calculations.

The product was then revised following the suggestion of the validation provided by two validators. The validation results provided by the two experts was presented in tables 3 and 4.

Table 3. Validity of Material Expert

\begin{tabular}{ccc}
\hline No & Aspect & Percentage \\
\hline 1 & Material & $84 \%$ \\
2 & Language & $80 \%$ \\
3 & Result of & $86 \%$ \\
\hline & Assessment/evaluation & $83.33 \%$ \\
\hline
\end{tabular}

Table 4. Validity of Media Expert

\begin{tabular}{ccc}
\hline No & Aspect & Percentage \\
\hline 1 & Display & $87 \%$
\end{tabular}

\begin{tabular}{ccc}
2 & Technical & $86 \%$ \\
3 & Constructive & $81 \%$ \\
\hline & Mean & $84.6 \%$
\end{tabular}

The results of the validation analysis provided by media experts on the HOT LAB-based EModule, obtained the percentage by $84.6 \%$. The aspects of the assessment assessed by media experts include the aesthetic display of the module, both the background and color, the technical use of the module in laboratory activities, and also the construct of the module in laboratory activities. The validators suggested considering the aesthetics, such as select the elegant color and color display between cover and content.

The pretest and posttest analyses of critical thinking skills were presented in Figure 3. The graph showed the mean score of pretest-posttest and $\mathrm{N}$-Gain for the experimental class and the control class. The mean score of the pretest in the experimental class was 54.67. While the mean score of the the pretest in control class was 35.53. And, the mean score of N-Gain in the experimental class was 64.51 and in the control class was 42.90 . 


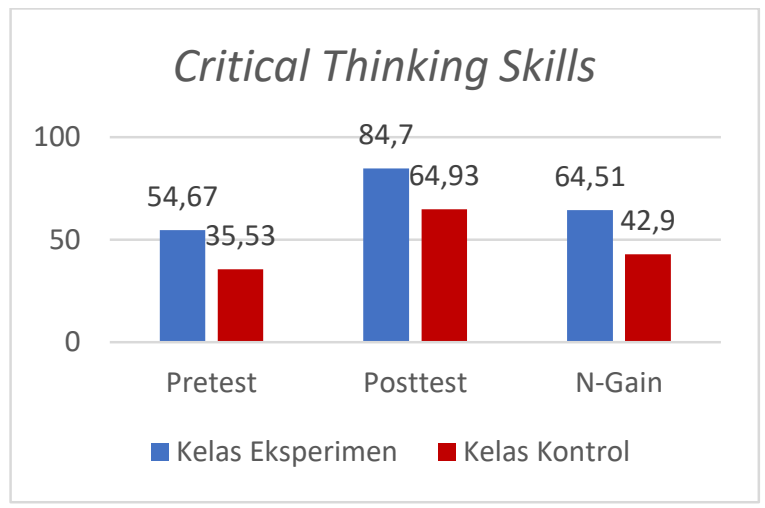

Figure 3. Mean Score of Pretest, Posttest, and NGain of Critical Thinking skills.

Figure 3 showed that the posttest and N-Gain scores in the experimental class were higher than the control class. Then, HOT LAB-based E-Modules in laboratory activities can increase the mean score of students in the experimental class compared to the control class. The finding was supported by previous research which showed HOT LAB can improve critical thinking skills (Sapriadil et al., 2019). Moreover, a research conducted by Suarsana (Suarsana \& Mahayukti, 2013), research on using EModules oriented towards problem-solving, also supported that the results of the pretest and posttest increase in both two classes, and the highest N-Gain value was in the Experiment class. And, supported by Diana, that using E-Module increases the pretest and posttest, and also reduced the level of misconceptions in a material concept (Diana et al., 2015)

The final product, shown in Figure 2, has passed the revision process and implemented to the subject that aimed to obtain the data and processed on statistical calculation. The statistical calculation on using E-Module was presented in Table 5.

Table 5. Different of mean score between Pretest and N-Gain on Critical Thinking Skill

\begin{tabular}{|c|c|c|c|c|c|}
\hline Score & Class & Mean Score & Normality & Homogenity & Significance \\
\hline & & & $\mathrm{X}^{2}{ }_{\text {Count }}<\mathrm{X}_{\text {Table }}^{2}$ & \multirow{4}{*}{$\begin{array}{l}\mathrm{F}_{\text {count }}<\mathrm{F}_{\text {Table }} \\
(2.30)<(2.35) \\
\text { (homogeneous) }\end{array}$} & \multirow{4}{*}{$\begin{array}{c}\mathrm{t}_{\text {Count }}<\mathrm{t}_{\text {Table }} \\
(0.594)<(1.672) \\
\begin{array}{c}\text { No Significant } \\
\text { change })\end{array}\end{array}$} \\
\hline \multirow{3}{*}{ Pretest } & Experiment & 54,67 & $\begin{array}{c}(9.1)<(9.487) \\
(\text { Normal })\end{array}$ & & \\
\hline & \multirow{2}{*}{ Control } & \multirow{2}{*}{35,53} & & & \\
\hline & & & $\begin{array}{c}(6.55)<(9.487) \\
(\text { Normal })\end{array}$ & & \\
\hline & & & $\mathrm{X}_{\text {Count }}^{2}<\mathrm{X}_{\text {Table }}^{2}$ & \multirow{4}{*}{$\begin{array}{l}\mathrm{F}_{\text {Count }}<\mathrm{F}_{\text {Table }} \\
(2.32)<(2.35) \\
\text { (homogeneous) }\end{array}$} & \multirow{4}{*}{$\begin{array}{c}t_{\text {Count }}>t_{\text {Table }} \\
(3.650)>(1.672) \\
\text { (There is a } \\
\text { Significant change) }\end{array}$} \\
\hline \multirow{3}{*}{$N$-Gain } & Experiment & 64,51 & $\begin{array}{c}(7.78)<(9.487) \\
(\text { Normal })\end{array}$ & & \\
\hline & & & $\mathrm{X}_{\text {Count }}^{2}<\mathrm{X}_{\text {Table }}^{2}$ & & \\
\hline & Control & 42,90 & $\begin{array}{c}(7.53)<(9.487) \\
(\text { Normal })\end{array}$ & & \\
\hline
\end{tabular}

Table 5 showed the data on increasing the score of Pretest-Posttest and N-Gain that calculated based on statistical data (Serungke et al., 2020). The data calculated statistically was presented in table 5 . The normal Chi-square test, where $\mathrm{X}^{2}$ Count $<\mathrm{X}^{2}$ Table, with $\alpha=0.05$, then the F-test is homogeneous, where $\mathrm{F}_{\text {Count }}<\mathrm{F}_{\text {Table, }}$ with $\alpha=0.05$, and t-test there was a significant change in $\mathrm{N}-$ Gain, where $t_{\text {Count }}$ $>t_{\text {table }}$ with $\alpha=0.05$.

The differences of the pretest score on students' critical thinking skills when using HOT LAB-based E-Module in table 2 were analyzed using t-test. The analysis showed that the experimental class obtained a score of 54.67 and the control class obtained a score of 35.53. The score showed the melan scores not significantly different. This means the pretest scores, both in the experimental and control classes were the same. Furthermore, the mean score of N-Gain obtained 64.51 in the experimental class and 42.9 in the control class. The increase of N-Gain Critical Thinking Skills scores of students who were given treatment showed a significant difference.

\section{CONCLUSION}

Based on the results and findings, concluded that the HOT LAB-based E-Module for students in laboratory activities of basic physics 2 had been successfully developed. This E-Module was in the good category as a guidebook for HOT LAB-based laboratory activities. The validation data provided by two validators obtained a mean percentage of $83.96 \%$ and was stated as valid. Then, the implementation of the HOT LAB-based E-Module was valid for use in HOT LAB-based laboratory activities.

The implementation of the HOT LAB-based E-Module in laboratory activities of basic physics 2 effectively improved students' Critical Thinking 
Skills that proved by the increase of the mean score of N-Gain critical thinking skills by 64.51 .

\section{REFERENCES}

Aji, R. F. (2007). Belajar mudah penelitian: untuk guru karyawan dan peneliti pemula.

Brooks, J. J. G., \& Brooks, M. G. (1999). In Search of Understanding: The Case for Constructivist Classrooms. Association for Supervision and Curriculum Development, 1-136. http://books.google.com/books?hl=en\&lr=\&i d=9W VB5TjxxoC\&pgis=1\%5Cnhttps://boo ks.google.co.uk/books?hl=en\&lr $=\& \mathrm{id}=9 \mathrm{~W} \_\mathrm{V}$ B5TjxxoC\&oi=fnd\&pg=PR7\&dq=+In+searc h+of+understanding:+The+case+for+construc tivist+classrooms.+Association+for+Supervis ion+and+Curriculum $+\mathrm{D}$

De, S. (1933). Thinking to The Educative Process, D. C . Heath and Company, 1933 ,.

Diana, N., Karyanto, P., Suciati, \& Indriyati. (2015). Penerapan E-Module Berbasis ProblemBased Learning untuk Meningkatkan Kemampuan Berpikir Kritis dan Mengurangi Miskonsepsi pada Materi Ekologi Siswa Kelas X MIPA 1 SMA Negeri 5 Surakarta Tahun Pelajaran 2014 / 2015 The Application of E-Module Based on Pro. Seminar Nasional XII Pendidikan Biologi FKIP UNS.

Eka Astika, Sri Anggraeni, \& Bambang Supriatno. (2020). Analisis Komponen Penyusun Desain Kegiatan Laboratorium Enzim Katalase. Biodik, 6(3), 343-356. https://doi.org/10.22437/bio.v6i3.9469

Hikmawati, H., Kosim, K., \& Sutrio, S. (2019). Desain Perangkat Pembelajaran Fisika Dengan Metode Real Experiments Dan Virtual Experiments. ORBITA: Jurnal Kajian, Inovasi Dan Aplikasi Pendidikan Fisika, 5(2), 88. https://doi.org/10.31764/orbita.v5i2.1303

Hoftein, A., \& Lunetta, V. N. (2003). The laboratory in science education: Foundation for 21st Century. Science Education, 88(1), $28-54$.

Kemendikbud. (2017). Panduan Praktis Penyusunan E-Modul Tahun 2017. Direktorat Pembinaan SMA Ditjen Pendidikan Dasar Dan Menengah.

https://awan965.files.wordpress.com/2017/09/ panduan_penyusunan-e-modul2017 final edit.pdf

Laelasari, I., \& Adisendjaja, Y. H. (2018). Mengeksplorasi Kemampuan Berpikir Kritis Dan Rasa Ingin Tahu Siswa Melalui Kegiatan Laboratorium Inquiry Sederhana. Thabiea: Journal of Natural Science Teaching, 1(1), 14.https://doi.org/10.21043/thabiea.v1i1.3879
Laili, I. (2019). Efektivitas Pengembangan E-Modul Project Based Learning Pada Mata Pelajaran Instalasi. Jurnal Imiah Pendidikan Dan Pembelajaran, 3, 306-315. https://ejournal.undiksha.ac.id/index.php/JIPP /article/download/21840/13513

Lastriningsih, L. (2017). Peningkatan berpikir kritis dan prestasi belajar melalui metode inquiry pada siswa kelas IV SD. Jurnal Prima Edukasia, $\quad 5(1), \quad 68-78$. https://doi.org/10.21831/jpe.v5i1.7714

Luckie, D. B., Smith, J. J., Cheruvelil, K. S., FataHartley, C., Murphy, C. A., \& Urquhart, G. R. (2013). The "Anti-Cookbook Laboratory": Converting "Canned" Introductory Biology Laboratories to Multi-week Independent Investigations. Proceedings of the Association for Biology Laboratory Education, 34(January), 196-213.

http://www.ableweb.org/volumes/vol34/luckie/supplement.htm

Makiyah, Y. S., Malik, A., Susanti, E., \& Mahmudah, I. R. (2019). Higher order thinking real and virtual laboratory (HOTRVL) untuk meningkatkan keterampilan abad ke-21 mahasiswa pendidikan fisika. Diffraction, l(1).

Malik, Adam; Setiawan, Agus; Suhandi, Andi ; Permanasari, A. (2018). Model Higher Order Thinking Laboratory (HOT-Lab).

Nurhadi, A. (2018). Manajemen Laboratorium Dalam Upaya Meningkatkan Mutu Pembelajaran. Tarbawi: Jurnal Keilmuan Manajemen Pendidikan, 4(01), 1. https://doi.org/10.32678/tarbawi.v4i01.832

Putra, R. P., \& Anjani, R. A. (2020). Analisis Pemahaman Siswa Kelas 12 di SMAN 1 Cileunyi terhadap pembelajaran Fisika Online selama pandemi CoVid-19. Jurnal Profesi Keguruan, 6(2), 167-173.

Putra, R. P., Silvianti, N., Idris, S. F., \& Nabilla, N. (2021). Uji Perbandingan Virtual Lab dengan Real Lab pada Hukum Archimedes. Radiasi : Jurnal Berkala Pendidikan Fisika, 14(1), 23 33.https://doi.org/https://doi.org/10.37729/rad iasi.v14i1.897

Rofiah, E., Aminah, N., \& Ekawati, E. (2013). Penyusunan Instrumen Tes Kemampuan Berpikir Tingkat Tinggi Fisika Pada Siswa Smp. Jurnal Pendidikan Fisika Universitas Sebelas Maret, 1(2), 120699.

Sapriadil, S., Setiawan, A., Suhandi, A., Malik, A., Safitri, D., Lisdiani, S. A. S., \& Hermita, N. (2019). Effect of Higher Order Thinking Virtual Laboratory (HOTVL) in Electric Circuit on Students' Creative Thinking Skills. Journal of Physics: Conference Series, 
Riki Purnama Putra, Rena Denya Agustina, at all/ JSER 2021 5(2), 49

1204(1). $\quad$ https://doi.org/10.1088/17426596/1204/1/012025

Serungke, M., Muhibbuddin, \& Suhrawardi. (2020). Implementation of problem-based learning (PBL) with virtual laboratory to improve students' critical thinking and achievement. Journal of Physics: Conference Series, 1460(1), 0-6. https://doi.org/10.1088/1742$\underline{6596 / 1460 / 1 / 012134}$

SETIABUDI NINGTYAS, A., \& ROSDIANA, L. (2019). Respon Peserta Didik Terhadap Keterlaksanaan Pembelajaran Menggunakan Model Guided Inquiry. Pendidikan Sains, 7(2), 9-13.

Suarsana, I. M., \& Mahayukti, G. A. (2013). Pengembangan E-Modul Berorientasi Pemecahan Masalah Untuk Meningkatkan
Keterampilan Berpikir Kritis Mahasiswa. Jurnal Nasional Pendidikan Teknik Informatika (JANAPATI), 2(3), 193. https://doi.org/10.23887/janapati.v2i3.9800

Syafitri, Y., Festiyed, Dwiridal, L., \& Afrizon, R. (2019). Pembuatan E-Modul Berorientasi Higher Order Thinking Skills (HOTS) Untuk Pembelajaran Fisika Pada Materi Kalor dan Teori Kinetik Gas di Kelas XI SMA/MA. Pillar of Physics Education, 12(4), 777-784.

Wena, I. M. (1970). Pengembangan E-Module Bermuatan Model Perubahan Konseptual Dalam Pembelajaran Fisika Di Sma. Jurnal Santiaji Pendidikan (JSP), 1(1), 97-110. https://doi.org/10.36733/jsp.v1i1.46 l(1), 8897. 